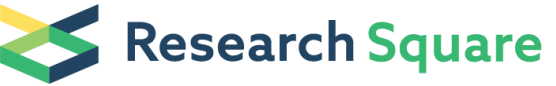

\section{Prioritizing Sponge City Sites in Rapidly Urbanizing Watersheds Using Multi-Criteria Decision Model}

\section{Xiaoyue Zhang}

Beijing Normal University

Lei Chen

Beijing Normal University

Meng Zhang

Beijing Normal University

Zhenyao Shen ( $\nabla$ zyshen@bnu.edu.cn )

Beijing Normal University, China https://orcid.org/0000-0001-5421-108X

\section{Research Article}

Keywords: Sponge City planning, Priority index, Macro scale, Multi-criteria model, Urbanizing watershed, AHP method

Posted Date: February 12th, 2021

DOI: https://doi.org/10.21203/rs.3.rs-166128/v1

License: (c) (1) This work is licensed under a Creative Commons Attribution 4.0 International License. Read Full License

Version of Record: A version of this preprint was published at Environmental Science and Pollution Research on July 6th, 2021. See the published version at https://doi.org/10.1007/s11356-021-14952-w. 
State Key Laboratory of Water Environment Simulation, School of Environment,

$5 \quad$ Beijing Normal University, Beijing 100875, P.R. China

6 Corresponding author: Lei Chen; Phone: +8610 58807031; fax: +8610 58807031; E-

7 mail: chenlei1982bnu@bnu.edu.cn.Zhenyao Shen; Phone: +86 10 58804733; fax: +86

$8 \quad 10$ 58800398;E-mail:zyshen@bnu.edu.cn. 
Abstract: Spatial planning is crucial for Sponge City (SC) construction; however, prioritizing SC sites at the watershed scale has not been fully explored. In this study, a multi-criteria decision model, considering demand and suitability of SC construction, was established by monitoring, model simulation and index calculation. This new model was then tested in a rapidly urbanizing watershed, Beijing, China and the priority of SC construction at both grid scale $(1 \mathrm{~km} \times 1 \mathrm{~km})$ and subwatershed scale was ranked. The results showed that the highest priority was found in emerging regions where urbanization is ongoing, and followed by urban core areas. In addition, six indexes were identified by clustering heatmaps as key factors affecting the priority of SC planning, including topographic index, water pollution index, pollution rate based on the state standard of surface water environment quality, urbanization planning, urban levels, and vegetation index, which could guide SC planning in data-lacking regions. The approach and findings in this study can not only provide helpful references for watershed managers and urban planners but also can be easily used in other regions.

Keywords: Sponge City planning; Priority index; Macro scale; Multi-criteria model; Urbanizing watershed; AHP method 


\section{Introduction}

Concerns about sustainable development of cities have increased globally due to rapid urbanization, which has changed the land use and land cover (LULC) considerably (Chatzimentor et al. 2020, Luan et al. 2019, Nguyen et al. 2020). As a result, natural hydrologic and ecological process have been impacted significantly by urbanization, followed by a variety of problems (i.e., urban flooding, stream degradation and ecological risk) (Lee et al. 2012, Liu et al. 2015, Zhang et al. 2017). Conventional urban construction, where independent infrastructures are constructed, ignores the resilient response capability, especially in terms of climate change and environmental risk (Rauch et al. 2017). Despite this, it is possible to implement practices for reducing urban problems and promoting a natural environment (Mustafa et al. 2018), such as Low Impact Development (LID), Best Management Practices (BMPs), Sustainable Urban Drainage Systems (SUDs) and Sponge City (SC) practices. An extensive adoption of green infrastructure to supplement conventional urban development is required. The application of green infrastructure reflects the mainstream narrative aiming to reconcile conflicting goals by integrating environmental concerns in decision-making processes of urban development (Apostolopoulou et al. 2014). Sponge city, which has been implementing in China since 2013, is regarded as an effective practice to improve urban resilience with respect to water and environmental system management. The focus of SC construction has shifted from the efficiency of individual facilities to systematic planning in recent years (Martin-Mikle et al. 2015). Optimal spatial layout planning can achieve comprehensive benefits, such as reducing 
runoff/pollutant loads by 3.9-7.7 times and placement costs by 4.2-14.5 times (Liu et al. 2016). Besides, hydrologically sensitive areas (HSAs) were employed to identify priority sites for LID implementation in a watershed with a geographic information system (GIS)-based framework and indicated $16 \%$ and $17 \%$ reductions in nutrient and sediment loads into receiving waters (Martin-Mikle et al. 2015). Scholars have also explored the optimal spatial scheme for facilities based on multi-objective models, including information on facility efficiency and cost (Hou et al. 2020a, Leng et al. 2020). The location of those facilities implemented within a watershed can be the most important factor in determining the effectiveness of SC construction (Jia et al. 2017). Although it is widely accepted that the construction of such strategies needs to consider ecological sensitivity and field suitability (Chan et al. 2018, Ishaq et al. 2019), systematic research on region selection at the macro scale is still in its infancy, which can easily lead to fragmentation of SC construction during urban planning.

However, the tools currently available to implement LID on a large scale are complex models (e.g., SUSTAIN, SWMM models), which require large amounts of data, such as monitoring data and detailed subsurface properties (Baek et al. 2020). The implementation of this process is especially difficult over a large scale in a city. In recent years, SC implementation has analyzed regional demands, including water issues and management, and regional suitability, such as location sites (Thu Thuy et al. 2020). This process is a multi-criteria and multi-objective decision-making process involving environmental, social, and economic issues. Therefore, a suitable model for decisionmaking is available to consider different weights to quantify qualitative criteria and 
compare different processes for multidimensional issues. The analytic hierarchy process (AHP) is one of the useful tools for multi-criteria analysis (Saaty 1980), and this tool has been applied to flood risk assessment with multiple criteria systems (Pantelidis et al. 2018). However, the AHP has not yet been systematically applied to SC construction, especially on a large scale, such as the urban scale or watershed scale. In this study, a typical urbanized watershed with a drainage area greater than 4000 $\mathrm{km}^{2}$ was set as a case study. The primary goal was to extend our knowledge of SC planning on a large scale. The objectives of this study were to 1) build a macro-scale and multi-criteria priority index (PI) model to quantify SC planning; 2) identify priority management units at the raster scale or regional scale for SC construction within a watershed; and 3) identify key factors affecting SC planning.

\section{Methodology}

\subsection{Study area}

The Beiyun watershed, the largest water system in Beijing, is a typically urbanizing watershed. Fig. 1 shows that the study area extends from the centre of Beijing to the northwest and southeast, with a total area of $4348 \mathrm{~km}^{2}$ and a total river length of $89.4 \mathrm{~km}$. Most of the watershed is relatively flat (elevation of 20 40 m), except for the northern forest area (elevation of 1000-1265 m). Within a warm temperate semi-humid continental monsoon climate, the average temperature is $11 \sim 13^{\circ} \mathrm{C}$. The annual precipitation is $500-600 \mathrm{~mm}$, with $80 \%$ received from June to August. The Beiyun watershed receives $90 \%$ of flood discharge, the water quality of which is related to water environmental security, human health and safety in Beijing. 
However, the water quality has been greatly affected by rapid urbanization.

The primary land uses in the study area in 2017 were recorded as urban (impervious surface accounted for 39.77\%) and agricultural land (accounting for $33.37 \%$ ). The urban areas are mainly located in the middle of the watershed with an impervious cover of over 70\%. Moreover, Fig. 2 shows that urbanization in the Beiyun watershed involves the transformation from agricultural land to impervious surfaces. Significantly, grassland (including grassland and wetland) and forest (including forest and shrubland) recovered in 2015, which may be a benefit from the implementation of SC construction since 2013. However, urbanization is continuously developed, and the adjacent areas of the city dominated by agricultural land use are awaiting transformation to meet the demands of urbanization. Urgently, how to integrate SC construction into urban development planning is a problem to be solved. The Beiyun watershed is a representative watershed that is experiencing rapid urbanization. As SC construction is indispensable to eliminate urban environmental problems, the Beiyun watershed is a reasonable study area for this issue. 


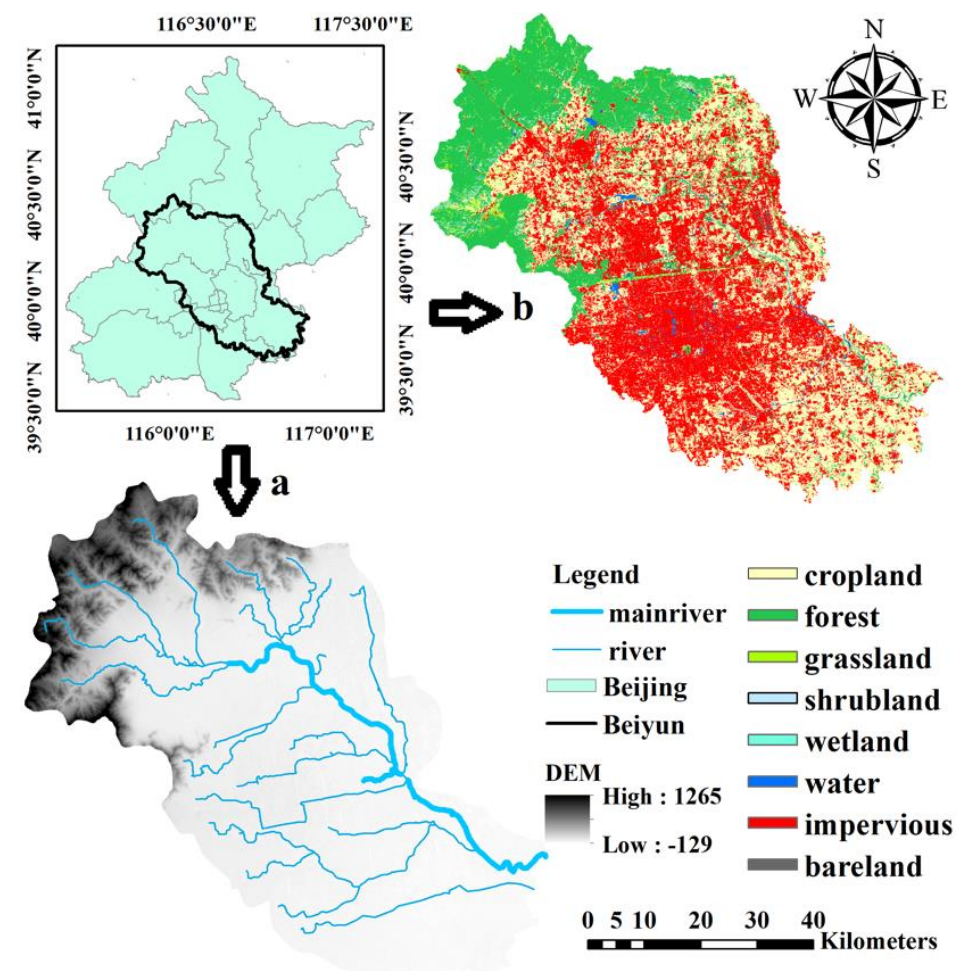

Fig. 1 Land use and elevation in the Beiyun watershed

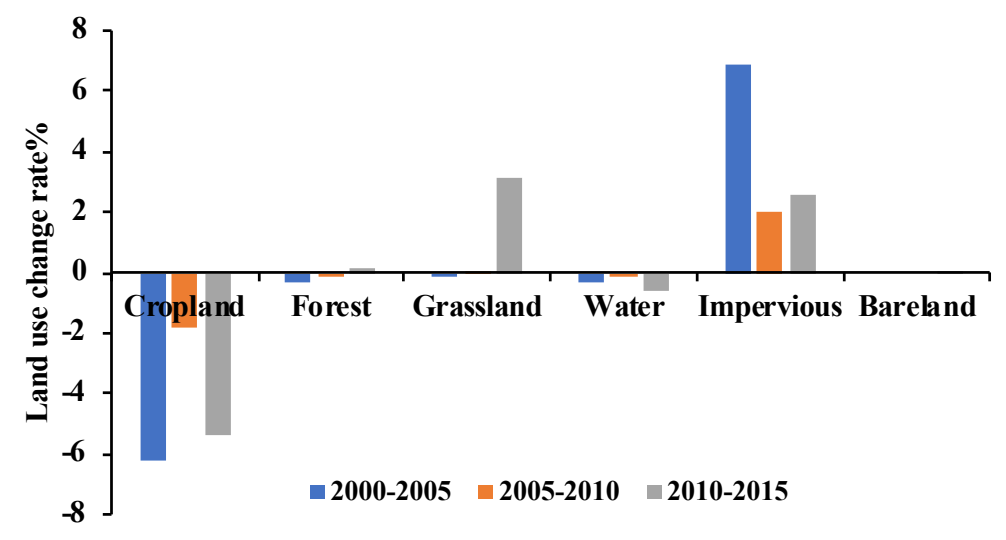

Fig. 2 Land use change in the study area

\subsection{Priority index model} is of great significance, as the assessments provide guidance for government officials

113 and stakeholders to develop sustainable cities and improve regional management and

114 planning efficiency. To comprehensively evaluate priority sites for SC construction at

115 the watershed scale, a multi-criteria priority index model was constructed. To compute 
116 index weights in the model, the IAHP method was introduced to balance the 117 comprehensive weights, which combined subjective weights from expert interviews 118 and objective weights from the CRiteria Importance Through Intercriteria Correlation 119 (CRITIC) method (Diakoulaki et al. 1995). After data normalization, the results were calculated with GIS-based weighted summation. seen in Fig. 3.

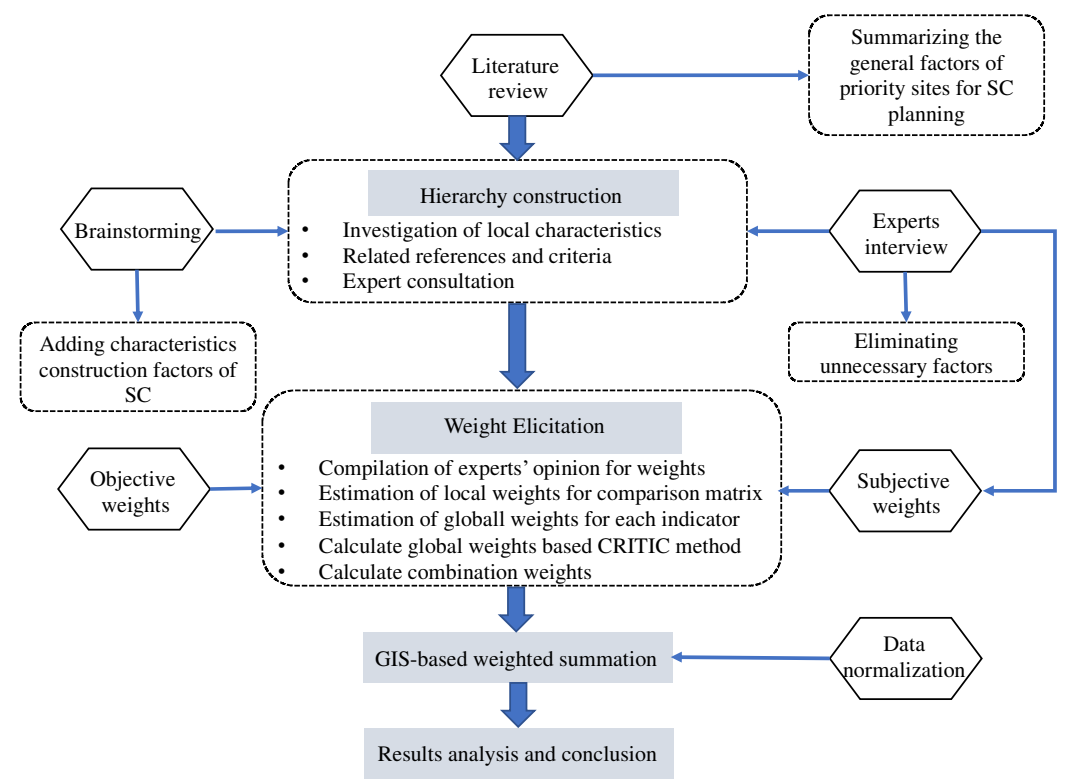

Fig. 3 Framework of this study

\subsubsection{Literature review}

Sustainable urban development has been popularizing globally to cope with environmental issues caused by rapid urbanization, which originated from urban stormwater management in developed countries in the 1970s (Pauleit et al. 2005). Sponge city was officially proposed in 2013 by Chinese government to solve the environmental problems with regional characteristics, which has been proved to have positive influences on urban water environmental, water ecology and water security 

construction into urban planning, based on the experiences during pilot period since 2015. To identify reasonable criteria for SC construction at a macro scale, various researches relating to site selection were collected and reviewed, as summarized in Table 1. Detailed information is provided in the supplementary materials. Five categories were concluded from the related literature, including climatic conditions,

138 demand for urban flood control, demand for urban pollution management, site 139 suitability and support from social development.

Table 1 Framework of criteria to evaluate site priorities of SC construction

\begin{tabular}{|c|c|c|c|}
\hline Criteria & indexes & Definition & Reference \\
\hline $\begin{array}{l}\text { Climatic } \\
\text { conditions }\end{array}$ & $\begin{array}{l}\text { Precipitation } \\
\text { Temperature }\end{array}$ & $\begin{array}{l}\text { Affect the selection of SC } \\
\text { facilities }\end{array}$ & $\begin{array}{l}\text { (Hou et al. 2020b, Qin et al. } \\
\text { 2013) }\end{array}$ \\
\hline \multirow[t]{3}{*}{$\begin{array}{l}\text { Urban flood } \\
\text { control }\end{array}$} & $\begin{array}{l}\text { Evaporation } \\
\text { Elevation } \\
\text { Slope }\end{array}$ & $\begin{array}{l}\text { Important topographic } \\
\text { factors affecting runoff } \\
\text { generation }\end{array}$ & $\begin{array}{l}\text { (Martin-Mikle et al. 2015) } \\
\text { (Martin-Mikle et al. 2015) }\end{array}$ \\
\hline & Soil permeability & $\begin{array}{l}\text { Important factors to mitigate } \\
\text { runoff }\end{array}$ & (Ahiablame et al. 2012) \\
\hline & Impervious cover & $\begin{array}{l}\text { Main factors of runoff } \\
\text { generation }\end{array}$ & (Martin-Mikle et al. 2015) \\
\hline \multirow[t]{2}{*}{$\begin{array}{l}\text { Surface water } \\
\text { pollution }\end{array}$} & $\begin{array}{l}\text { Water pollution } \\
\quad \text { index }\end{array}$ & $\begin{array}{c}\text { General pollution status of } \\
\text { rivers }\end{array}$ & $\begin{array}{c}\text { (Charlesworth et al. 2016, Han } \\
\text { et al. 2020) }\end{array}$ \\
\hline & $\begin{array}{l}\text { Urban NPS } \\
\text { contribution }\end{array}$ & $\begin{array}{c}\text { Contribution ratio of NPS to } \\
\text { river pollution }\end{array}$ & (Ma et al., 2018) \\
\hline \multirow[t]{4}{*}{ Site suitability } & River buffer & River shoreline & (Shen et al. 2015) \\
\hline & Land use & $\begin{array}{l}\text { Site suitability of SC } \\
\text { construction }\end{array}$ & $\begin{array}{c}\text { (Charlesworth et al. 2016, Jia et } \\
\text { al. 2013) }\end{array}$ \\
\hline & Vegetation index & $\begin{array}{l}\text { Characterizing regional } \\
\text { ecological sensitivity }\end{array}$ & (MOHURD, 2019) \\
\hline & Urban levels & Construction space of SC & (Jia et al. 2013) \\
\hline \multirow[t]{2}{*}{$\begin{array}{c}\text { Social } \\
\text { development }\end{array}$} & Population density & $\begin{array}{c}\text { Human activity intensity and } \\
\text { potential disaster risk }\end{array}$ & (Nguyen et al. 2020) \\
\hline & GDP & $\begin{array}{c}\text { Financial support for SC } \\
\text { construction }\end{array}$ & $\begin{array}{l}\text { (Hou et al. 2020a, Jia et al. } \\
\text { 2013) }\end{array}$ \\
\hline
\end{tabular}




\begin{tabular}{cccc}
\hline Criteria & indexes & Definition & Reference \\
\hline urbanization & Urban future development & (Charlesworth et al. 2016, \\
planning & planning & Nguyen et al. 2020) \\
& Public opinion & Public acceptance of SC & (Brown et al. 2016) \\
\hline
\end{tabular}

\subsubsection{Construction of index system}

The brainstorming method provides unique chance for researchers to discuss their opinions freely and positively (Osborn 1957). To initially assess and adjust the evaluating indicators for priority site selection of SC construction at macro-watershed scale, brainstorming method was introduced in this study to improve the reliability of the hierarchical structure considering the suitability and demand of SC construction. Afterward, expert interview method was employed twice to construct the final hierarchical framework (using NetMeeting and Email) and determine the weights (using questionnaire survey), respectively (Zhang et al. 2019). Consulting qualified experts is vital to establish credibility. Therefore, 42 experts were included, who came from universities, research institutions, the China Academy of Urban Planning and Design, and the government. The arithmetic mean was used to aggregate the experts' opinions. The findings are presented in Section 3.

\subsubsection{Calculation of weight}

The AHP method, as one of the most useful multi-criteria approaches, determines index weights based on the subjective attributes (Saaty 1980). Comparatively, the CRITIC method can estimate the objective importance by incorporating both contrast intensity and conflict of a decision structure (Diakoulaki et al. 1995). Accordingly, we introduced IAHP method by combining the subjective weights generated by AHP and objective weights generated by CRITIC to comprehensively determine index weights. 
Specifically, three steps were involved, as shown below:

(1) Subjective weights generated by AHP method

The AHP method decomposes goals or problems into several hierarchies, and the index weights in each hierarchy were determined by experts' judgement. The pairwise comparison matrix was constructed according to the collected judgments made by experts, as shown below:

$$
\boldsymbol{A}=\left(M_{i j}\right)_{n \times n}=\left[\begin{array}{cccc}
M_{11} & M_{12} & \cdots & M_{1 n} \\
M_{21} & M_{22} & \cdots & M_{2 n} \\
\vdots & \vdots & \vdots & \vdots \\
M_{n 1} & M_{n 2} & \cdots & M_{n n}
\end{array}\right]
$$

where $M_{i j}$ is the relative importance of factor $i$ to factor $j$, computed by pairwise comparison with nine-quantity measurements (Table S1).

Thereafter, the relative importance of each criterion could be obtained using Eq. (2), where the normalized values of matrix $\boldsymbol{A}$ were determined by Eq. (3).

$$
\begin{array}{cc}
W_{i}^{*}=\sum_{j=1}^{n} M_{i j}^{*} & \forall i=1,2, \cdots, n \\
M_{i j}^{*}=\frac{M_{i j}}{\sum_{j=1}^{n} M_{i j}} & \forall i \& j=1,2, \cdots, n
\end{array}
$$

The index weight vector was calculated using Eq. (4):

$$
W_{i}^{\prime}=\frac{W_{i}^{*}}{\sum_{i=1}^{n} W_{i}^{*}} \quad \forall i=1,2, \cdots, n
$$

The consistency of index relative importance in each hierarchy should be examined to determine the reliability of index weights. Therefore, the consistency rates have to be calculated by Eq. (5). These indexes are considered to pass the consistency test with CR less than 0.1 .

$$
C R=\frac{C I}{R I}
$$




$$
\begin{aligned}
C I & =\frac{\lambda_{\max }-n}{n-1} \\
\lambda_{\max } & =\frac{1}{n} \sum_{i=1}^{n} \frac{(m w)_{i}}{w_{i}^{\prime}}
\end{aligned}
$$

where RI is a random index, given in Table S2; CI is the consistency index; and $\lambda_{\max }$ is the eigenvalue maximum.

(2) Objective weights generated by CRITIC method

In the CRITIC method, each criterion $C_{i}$ contains a certain amount of information, which can be quantified by Eq. (8). A higher $C_{i}$ value indicates larger amount of information, showing higher importance in the decision-making process.

$$
C_{i}=\sigma_{i} \cdot \sum_{k=1}^{m}\left(1-r_{i k}\right) \quad \forall i=1,2, \cdots, n
$$

where $\sigma_{i}$ is the standard deviation of $i$; and $r_{i k}$ is the correlation degree between the vectors $X_{i}$ and $X_{k}$.

These values were normalized to uniform objective weights according to Eq. (9).

$$
W_{i}^{\prime \prime}=\frac{C_{i}}{\sum_{k=1}^{m} C_{k}} \quad \forall i=1,2, \cdots, n
$$

(3) Comprehensive weights generated by IAHP method

To balance the subjective intention and objective impartiality of AHP method and CRITIC method, the mean values of the two methods were taken as the comprehensive weights. Comprehensive weights $W_{i}$ were computed by Eq. (10).

$$
W_{i}=\frac{W_{i}^{\prime}+W_{i}^{\prime \prime}}{2} \quad \forall i=1,2, \cdots, n
$$

where $W_{i}^{\prime}$ denotes the subjective weight determined by the AHP method.

\subsubsection{Priority index (PI)}

To compare and weight data with different units or orders of magnitude, data 
normalization was employed to transform data sources into dimensionless scores ranging from 0.00 to 1.00 . Data normalization was computed through the fuzzy membership tool in ArcGIS software.

After weighted and scored, GIS-based weighted summation was performed using Eq. (11):

$$
P I=\sum_{i=1}^{n} W_{i} \times S_{i}
$$

where $W_{i}$ is the comprehensive weight; $S_{i}$ is the index score; and $n$ is index quantity. Afterwards, the spatially-detailed time sequence of SC construction can be quantified according to the $P I$ model.

\subsection{Data acquisition and pre-process}

\subsubsection{Runoff control indexes}

Runoff is mainly affected by topography and landscape, including elevation, slope, soil permeability and impervious cover. Soil conductivity and soil depth are from the Soil Science Database. Soil data and impervious surface cover in 2017 are available at the Department of Earth System Science, Tsinghua University. A 30-m digital elevation model (DEM) from Resource and Environment Data Cloud Platform was processed using the ArcGIS hydrology toolset to develop slope and elevation.

However, we did not determine weights for the four indexes by AHP. The topographic index has been identified as evidence for generating runoff that can alter stream hydrology and potentially transport pollutants to streams (Beven \&Kirkby 1979). Thus, we built an improved topographic index, which can cover this information perfectly based on the wetness index. The wetness index $\lambda$ calculated by Eq. (12) is 
unitless, used to model surface runoff contribution area.

$$
\lambda=\ln \left(\frac{\alpha}{\tan \beta}\right)
$$

214 where $\alpha$ represents the surface runoff contribution area of 1-meter contour length; and $215 \beta$ is the slope in radians $(\beta>0)$.

216 However, this index masks the soil water storage capacity. Besides, the impervious surfaces in urban regions deprive the soil water storage capacity. So, we improved a

218 modified topographic index (TPI) to extend the usability of topographic index in 219 urbanized areas, as shown in Eq. (13)-(14).

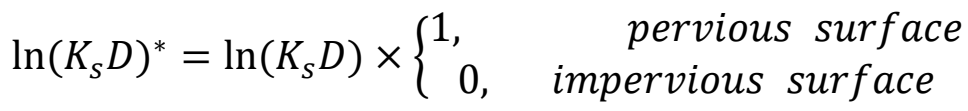

$$
\begin{aligned}
& T P I=\ln \left(\frac{\alpha}{\tan \beta}\right)-\ln \left(K_{S} D\right)^{*}
\end{aligned}
$$

where $K_{S}$ is the soil hydraulic conductivity (m/day); and $D$ refers to soil depth of restrictive layer $(\mathrm{cm})$ with a maximum value of $200 \mathrm{~cm}$.

\subsubsection{Surface water quality indexes}

Surface water quality indexes were obtained from river monitoring and the SPARROW model simulation. YPL and U-NPS of each subwatershed, as well as the pollutant concentration of each river section could be obtained from the calibrated model. Detailed information about the SPARROW model and simulation results were shown in Fig. S1-S4.

PR was calculated by the ratio of the monitoring concentration to the regional Environmental Quality Standards for Surface Water (EQSSW). Sample sites and collection were shown in our previous study (Zhang et al. 2020).

$$
\mathrm{PR}=\frac{n}{N} \times 100 \%
$$


where $n$ is the quantity of collected samples in a sampling site that are beneath the water quality standards based on the required EQSSW; and $N$ is the total number of collected water samples in a sampling site. computed by Eq. (16).

$$
\mathrm{WPI}=\sum_{i=1}^{n} W_{i} \times C_{i}
$$

where $\mathrm{n}$ is the total number of water quality indicators $\left(\mathrm{NH}_{3}-\mathrm{N}, \mathrm{TP}, \mathrm{COD}, \mathrm{FC}, \mathrm{SS}\right) ; W_{i}$ is the weight of the $i$ th indicator; and $C_{i}$ is the normalized concentration of the $i$ th indicator. Remarkably, indicator weights were determined by the pollution levels of each indicator, which were obtained according to percentage of river sections exceeding standard Class V of surface water quality. The percentages were normalized to be the weights (Table S3).

Although PR and WPI reflect the water quality of river sections, they were transformed into raster data for GIS weighted summation with other data. This method is understandable, because river water quality represents the regional surface water environment.

\subsubsection{Site suitability indexes}

Land use and vegetation index data are available at the Resource and Environment Data Cloud Platform. We defined whether each type of land use permitted LID implementation according to previous studies (Charlesworth et al. 2016), and the suitability of five levels and scores are shown in Table S4. Besides, MOHURD (2019) claimed that the SC construction should protect ecologically sensitive areas, so the 
development of areas with high ecological sensitivity should be restricted. The vegetation index is a simple, effective and empirical measure of vegetation status and can thus be used as an alternative indicator of ecological sensitivity. The urban level was quantified by the impervious surface ratio, which represented the SC construction space; the higher the urban level, the smaller the construction space, resulting in lower priority. However, the urban level with less than $30 \%$ impervious cover was set to the lowest priority because SC construction aims to solve water problems in urban areas. Moreover, the river buffer is the distance to the river, which was calculated in ArcGIS using Spatial Analyst tools. Previous study indicates that landscape patterns have different influences on water quality at diverse buffer zone scales (Shen et al. 2015). Thus, the river buffer was divided into five levels: 0-100 m, 100-500 m, 500-1000 m, 1000-1500 m, and $>1500 \mathrm{~m}$, with standardized scores of 100, 80, 60, 40 and 20 .

\subsubsection{Social development indexes}

Population density and GDP data are available at the Resource and Environment Data Cloud Platform. Urbanization planning (UP) was characterized by the growth rate of impervious surfaces (Eq. (17)). A higher UP value indicates that a region is in the process of urbanization, where it is considered a priority site to integrate into sponge city planning.

$$
\mathrm{UP}=\frac{I M_{2015}-I M_{2010}}{I M_{2010}}
$$

where $I M_{2015}$ and $I M_{2010}$ are the impervious surface ratios in 2015 and 2010.

\subsection{Priority site assessment and verification}

To find priority areas at either the raster scale or regional scale within a watershed, 
cluster analysis was introduced in this study. The iterative self-organizing (ISO) cluster and maximum likelihood classification were combined for priority site clustering analysis. The ISO cluster is most often used in the preparation of partitioning, unsupervised and iterative clustering algorithms, which uses a process where each iteration computes the minimum Euclidean distance when assigning each candidate cell to a cluster. Most classification objects are improbable to appear during the initial stage of cognition or classification. More detailed information relating to ISO cluster can be found in previous studies (Ball \&Hall 1965, Richards 1986). Thereafter, the resulting signature file from the ISO cluster algorithm was put into the maximum likelihood classification, during which classification parameters can be designed accordingly. All the processes were completed using ArcGIS techniques, enabling priority sites for SC planning to be obtained for scientific analysis.

To verify the effectiveness of the method that was produced to prioritize SC sites at the watershed scale, we selected 3 sites stochastically to validate the effectiveness through filed visits, because changes may occur after data collection (e.g. construction), or space becomes limited owing to coarse-resolution land use data. Spatial heterogeneity of LULC characterizes urban patterns (Luo et al. 2020). The suitability was determined based on the feasibility of facilities implementation at a specific site. The GIS-based remote sensing possesses advantages to prioritize potential SC sites, outperforming the expensive and time-consuming approach to access all potential sites across watersheds.

\subsection{Statistical analysis}



priorities were explored at the subwatershed scale, where regional characteristics could be characterized more easily. We calculated the mean values of the indexes in each subwatershed in ArcGIS using Spatial Analyst tools and prioritized the subwatersheds using the ISO-maximum likelihood method. The normalized index values of each subwatershed of different priority levels were calculated in SPSS software. The inherent diversity and complexity of regional characteristics requires statistical descriptions to better understand how the evaluation index may influence the priority of SC planning. Hierarchical clustering provides unsupervised classification of all selected factors to identify characteristic factors. Thus, heatmaps of indexes in different priority regions values were visualized.

\section{Results}

\subsection{The construction of priority index model}

Four criteria, including fifteen indexes, were recognized through brainstorming and expert interviews (Fig. 4). More specifically, in addition to the general factors, another two priority factors were added ("yield of pollution load" and "pollution rate based on EQSSW") owing to pollution characteristics of complex watersheds. After that, the initial priority list was further subjected to modification in the next expert interview. The same opinions were proposed that four factors ("precipitation", "temperature", "evaporation" and "public opinion") were excluded in this hierarchy structure, because of little spatial heterogenicity in the Beiyun watershed. 
Based on the detailed description in Section 2.2.3, the index weights were calculated. The pairwise comparison matrix of the criterion layer and index layer according to experts' suggestions of AHP were shown in Tables S5-S8. The value of CR was within acceptable limits $(<0.1)$, so the suggestions from experts were reasonable. Table 2 illustrates the weights of each index. The results of W-C showed that surface water quality was the most important indicator with a weight of 0.3784 , followed by runoff control indicator with a weight of 0.3441 . This result could be runoff floods, is the priority target of SC construction (Li et al. 2019, Lin et al. 2020), between which water pollution is the first priority (Leng et al. 2020). The next most for example, financial conditions provide a foundation for SC construction but largely depend on investment from government at present (Zhang et al. 2019). 


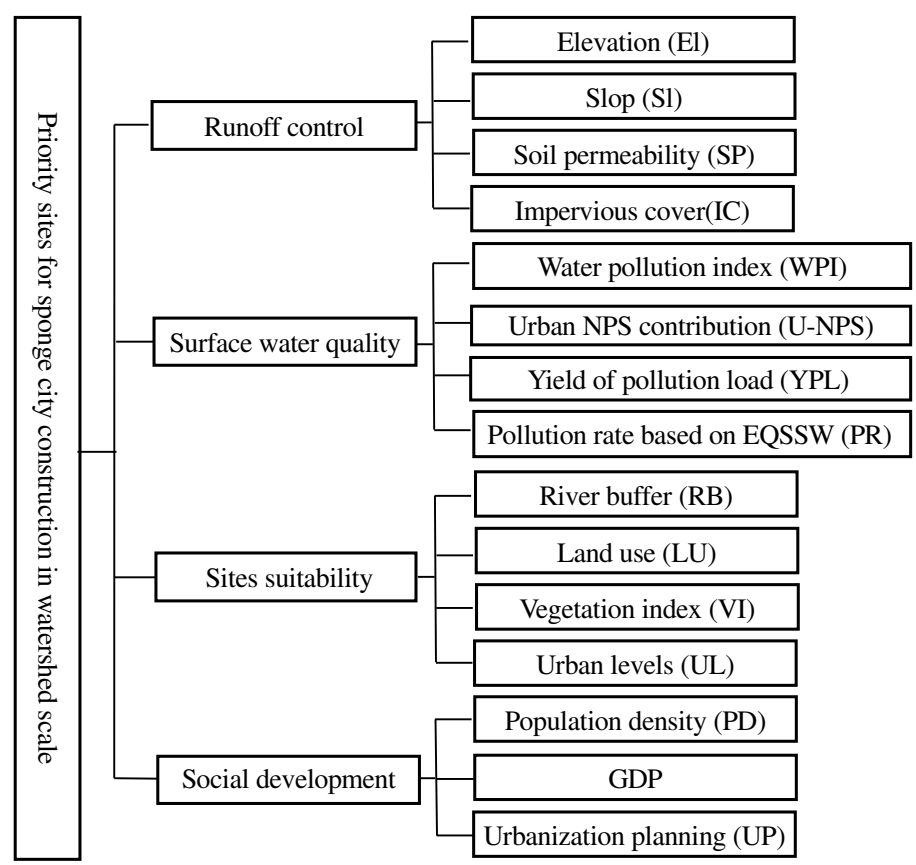

Fig.4 Hierarchical structure of SC planning in the Beiyun watershed

Table 2 Weights of the SC planning index

\begin{tabular}{cccccccc}
\hline Criterion & $W_{G}^{\prime}-\mathrm{C}^{\mathrm{a}}$ & Index & $W_{L}^{\prime}{ }^{\mathrm{b}}$ & $W_{G}^{\prime}-\mathrm{I}^{\mathrm{c}}$ & $W^{\prime \prime} \mathrm{d}$ & $W-\mathrm{C}^{\mathrm{e}}$ & $W-\mathrm{I}^{\mathrm{f}}$ \\
\hline Runoff control & 0.38 & $\mathrm{El}$ & $(\mathrm{TPI})$ & 0.38 & 0.1143 & 0.3441 & 0.3441 \\
& & $\mathrm{Sl}$ & & & 0.0136 & & \\
& & $\mathrm{SP}$ & & & 0.1682 & & \\
Surface water & 0.37 & IC & & & 0.0122 & & \\
quality & & PR & 0.29 & 0.1073 & 0.1679 & 0.3784 & 0.1376 \\
& & YPL & 0.32 & 0.1184 & 0.1047 & & 0.1115 \\
& & U-NPS & 0.18 & 0.0777 & 0.0678 & & 0.0728 \\
Sites & 0.15 & RB & 0.39 & 0.0585 & 0.0927 & 0.1477 & 0.0755 \\
suitability & & LU & 0.27 & 0.0405 & 0.0136 & & 0.0271 \\
& & VI & 0.20 & 0.0300 & 0.0203 & & 0.0252 \\
& & UL & 0.14 & 0.0210 & 0.0188 & & 0.0199 \\
Social & 0.10 & PD & 0.41 & 0.0410 & 0.0585 & 0.1298 & 0.0498 \\
development & & GDP & 0.26 & 0.0260 & 0.0466 & & 0.0363 \\
& & UP & 0.33 & 0.0330 & 0.0543 & & 0.0437 \\
\hline
\end{tabular}

339 weights of AHP for index; ${ }^{\mathrm{d}} W^{\prime \prime}$ : Objective weights; ${ }^{\mathrm{e}} \mathrm{W}-\mathrm{C}$ : Combination weights for criterion; ${ }^{\mathrm{f}}$

340 W-I: Combination weights for index. 

shows the result of the priority index result of SC planning, which ranged from 0.0490.764 and exhibited a near normal distribution (Fig. 5c). Priority areas on the raster scale $(1 \mathrm{~km} \times 1 \mathrm{~km})$ corresponding to the priority index were generated based on the ISO-maximum likelihood clustering algorithm, according to which five levels were compared. Fig. 5b describes the spatial distribution of priority areas, where low priority areas (priority 1 and priority 2) accounted for $49.07 \%$ and the highest priority areas accounted for $15.03 \%$ (Fig. $5 \mathrm{~d})$.

In the Beiyun watershed, the areas of priority 5 were more prominent in the middle of the main stream, as well as the middle and lower reaches of the watershed where 
generally exhibit good surface water quality, which supports the conclusions from previous studies that urban surface water quality has been improved over the past decade (Han et al. 2020). However, despite the limited space, these areas were selected as priority 4 due primarily to low infiltration capacity that results from large impervious surface areas of this region (over $60 \%$ impervious cover) with a topographic index of over 8. Martin-Mikle et al. (2015) also considered areas with a topographic index above 8.79 as hydrologically sensitive areas, based on which priority sites for LID implementation were identified. Additionally, if a flash flood occurs in these areas, there will be a large number of casualties and property losses due to the dense populations and high property concentration, which was consistent with what was widely reported by previous individual studies (Lin et al. 2020). Therefore, the SC construction in urban built-up areas should focus on flood management.

The areas with priority 3 surrounded the urban core areas (priority 4) and were in the middle and upper reaches of the watershed. Thus, if the resources are sufficient, including funds, government support, and human resources, etc., then SC planning and construction can be carried out in these areas. At present, SC construction is not recommended in priority 1 and 2 areas that are located upstream and downstream of the watershed, where forestland and agricultural land account for large proportions (over $40 \%$ and $50 \%$, respectively). In theory, numerous suitable sites can be identified. However, social, economic and environmental benefits may decline as high-priority sites give way to low priority sites (Lin et al. 2020). We focused on the priority areas for SC planning to demonstrate where, along a continuum of benefits, the greatest return 
would be realized.
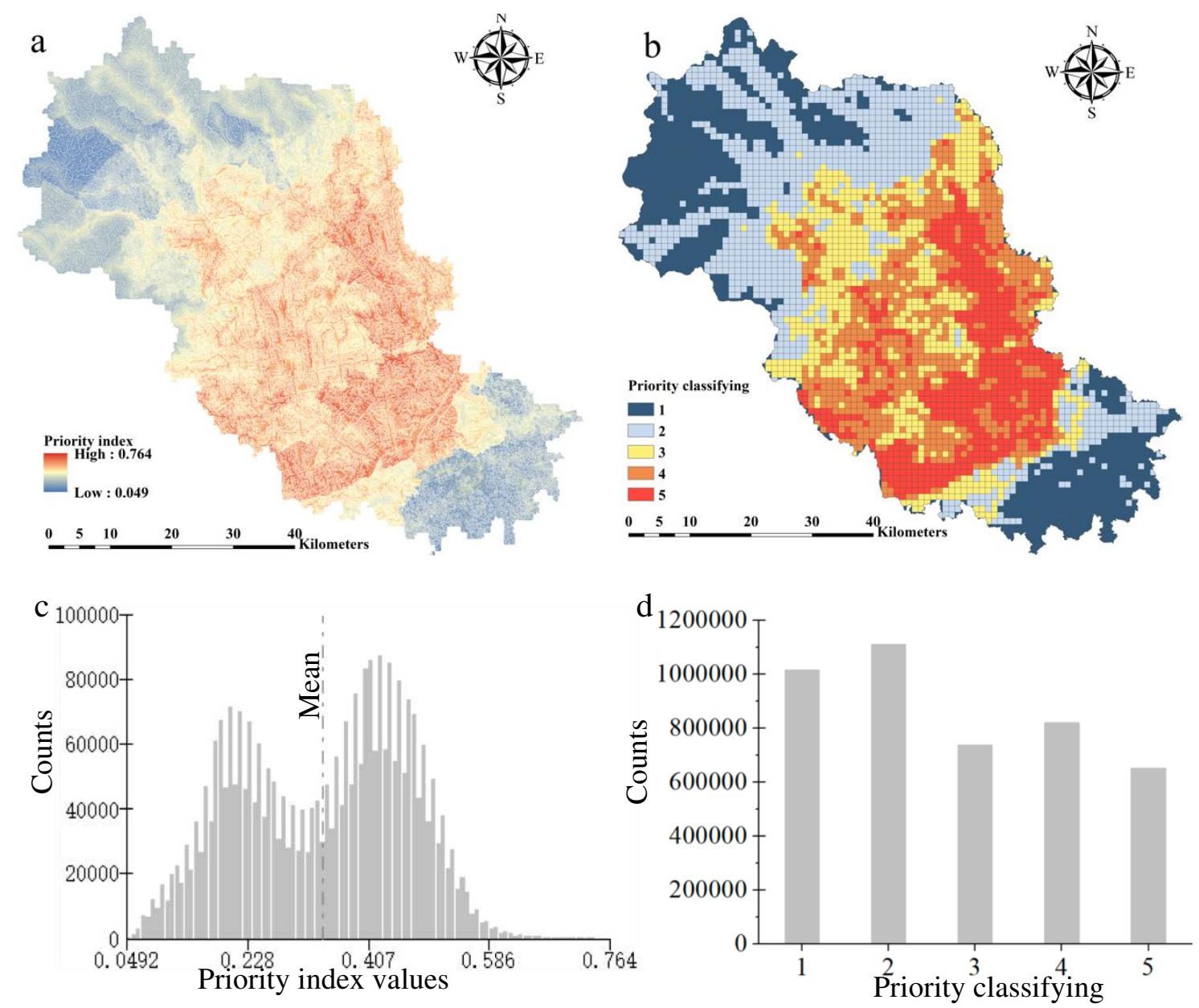

Fig. 5 Spatial distribution of priority sites for SC construction in the Beiyun watershed

\subsection{Verification}

Land use and elevation of the study area (Fig. 1) show that the northern part of the watershed is mountain areas and country parks where there is a low residential density.

Besides, although the lower watershed is plain, which is conducive to the construction and implementation of LIDs, there are almost no residential areas or commercial areas in this area. Both of the areas mentioned above are consistent with the low priority in our study. The areas surrounding the center of the watershed are newly built-up areas, which is the best time for SC integration, supporting the highest priority for LID construction in these areas. The center of the watershed (core areas and downtown areas) 
is still a high density of residential and commercial areas accompanied by a high risk

399 of casualties and property losses when facing disasters (Lin et al. 2020), requiring a

400 higher priority of SC construction. So, the spatial distribution of priority sites, shown

401 in Fig. 5, is reasonable.

The suitability of the three selected validation sites were verified through field

403

404

405 survey (Fig. 6). There was a considerable area of bare land and under construction land that will provide enough space to facilitate bioretention ponds, which would be possible to manage runoff and pollutants from adjacent areas. The riparian buffer was the ideal site for LID implementation (such as riparian buffer) to slow and filter runoff. Besides, the validation sites contained buildings and roads with different densities where green roofs, rain barrels and porous pavement could be suitable facilities for treating runoff volume and quality. Briefly, the priority is reasonable, as the verification sites not only demonstrate the suitability of land use but also suggest that there is sufficient space in these areas to construct sponge facilities.

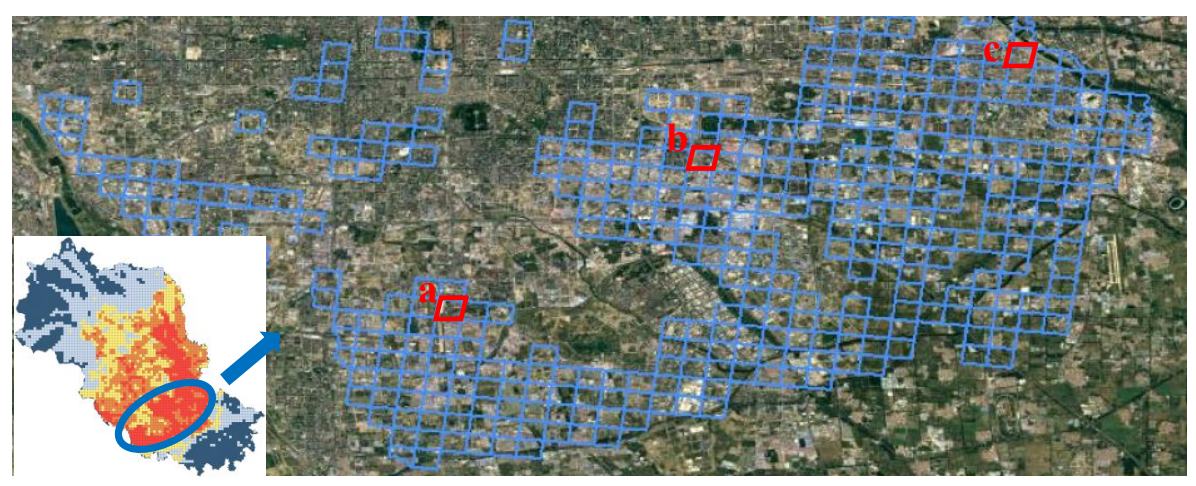

Fig. 6 Sites validation of the priority for LID implementation

\section{Discussion}

\subsection{Advantages of the PI model}

Sponge City planning has been demonstrated to be a multi-criteria and multi- 
417 objective decision-making process involving environmental, social, and economic 418 issues (Thu Thuy et al. 2020). The present study reveals that 15 priority factors were

419 included in watershbed-scale SC planning. The PI model is shown below, according to

420 which the time sequence of SC construction at the raster scale or subwatershed scale 421 can be quantified.

$$
\begin{aligned}
P I=\sum_{i=1}^{n} W_{i} \times S_{i} & \\
& =0.3441 \times \text { "runoff control" }+0.3784 \times \text { "surface water quality" }+0.1477 \times \\
& \text { "sites suitability" }+0.1298 \times \text { "social development" } \\
& =0.3441 T P I+0.1376 W P I+0.1115 P R+0.0565 U-N P S+0.0728 Y P L+0.0755 R B+ \\
& 0.0271 L U+0.0252 V I+0.0199 U L+0.0498 P D+0.0363 G D P+0.0437 U P
\end{aligned}
$$

Although there has been generous research on coupling multi-objective decision support systems and mechanism models (e.g., SUSTAIN, SWMM) to optimize LID sites and combinations (Leng et al. 2020), most of these studies focused on the community scale and catchment scale, which has pushed SC planning to fragmentation (Ishaq et al. 2019). Determining spatial planning on a large scale is a challenging task owing to complicated contexts. Notwithstanding that SC planning and implementation are subject to substantial variabilities across influence factors and scenarios (Zhang et al. 2019), Martin-Mikle et al. (2015) identified priority sites for LID in a mixed-use

430 watershed through hydrologically sensitive areas by calculating the topographic index.

431 We admit that this is an important basis; however, more factors should be considered.

432 Thus, the PI model in this study integrated micro-scale multi-objectives into macro433 scale planning, which provides intelligible theory for the PI model in this study and will 
bridge the gap between macro-scale master planning and micro-scale facility layout.

The PI model will provide a unique chance to quantify the effect of SC on surface water bodies more easily in a watershed. Besides, fewer strategical construction allows for more affordable and consistently manageable SC projects. Additionally, from the perspective of mechanism, the method and systematic framework in this study should perform well in any region, although specific model parameters and coefficients may need to be recalibrated to more accurately plan SC construction on a large scale.

\subsection{Management implications}

It is clear that any policy or initiative aimed at maximizing the sponge effect must consider the priority of SC planning, given that it is a spatial multi-criteria and multiobjective decision-making process. The varying PI in our study highlights the urgent and important opportunities to implement SC in emerging regions where large area of buildings and infrastructures have yet to be constructed, which tracks with other research showing that emerging regions are optimal areas to mitigate carbon emissions owning to sufficient construction space (Cao et al. 2020). To avoid environmental problems during urbanization development, emerging regions should avoid replicating the patterns of urban planning from developed regions and instead pursue a LID strategy to achieve sustainable cities (Chatzimentor et al. 2020, Hou et al. 2020a).

Fig. 7 shows the subwatershed-scale priority of SC planning. The total area of subwatersheds with the highest priority accounted for $18.70 \%$, followed by $26.45 \%$, $12.22 \%$ and $42.63 \%$ (priority 2 and priority 1 ). The spatial distribution of priority is similar to that in Fig. $5 \mathrm{~b}$ (see detailed discussion in Section 3.2). Fig. 8 shows the 
clustering results of the index at different priority levels. The high-priority regions generally exhibit higher WPI, PR and TPI, which is in line with the goals of SC construction. These findings are consistent with other research showing that SC is effective in managing surface water quality and urban flooding (Leng et al. 2020, Martin-Mikle et al. 2015). Besides, higher UP and lower UL provide sufficient construction space and unique opportunity for SC planning. Cao et al. (2020) also highlighted the priority of emerging regions to mitigate carbon emissions. Thus, $\mathrm{SC}$ is projected to become much more limited as the urban level rises. Fig. $8 \mathrm{~b}$ shows that higher UL and lower UP reduced the priority compared to that in Fig. 8a. Moreover, a higher VI pushed SC planning to its lowest priority, as shown in Fig. 8c and 8d. The development of ecologically sensitive areas is restricted; thus, urban planning is not allowed, and some non-structural measures may suit these regions (Lintern et al. 2020). Briefly, our analysis revealed that TPI, WPI, PR, UP, UL and VI are key factors affecting the regional priority for SC planning on a macro scale, which suggests that these six factors can be used as an alternative index for evaluating the priority of SC construction when a sufficient evaluation index is lacking. These insights in this study should be consistently included in SC planning toward facilitating the long-term mitigation of environmental problems during global urbanization. 


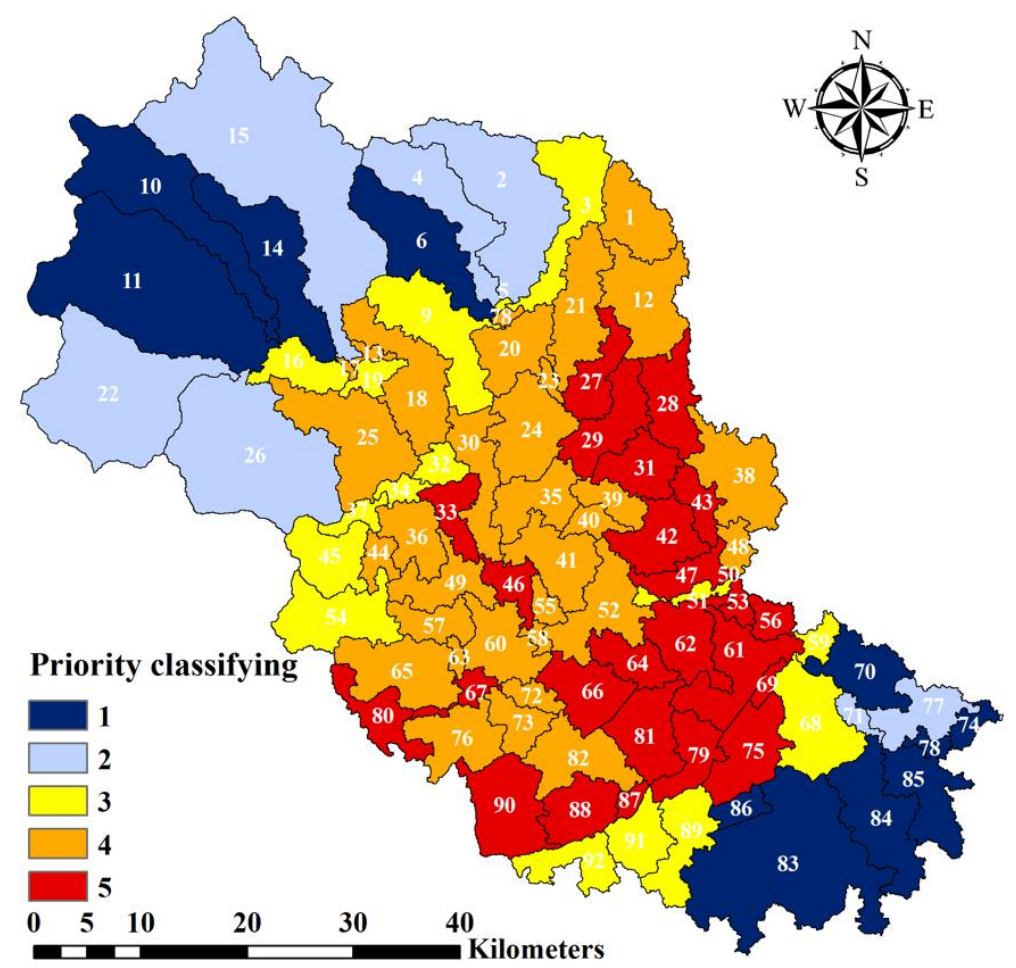

Fig. 7 Priority of SC planning in subwatershed scale

a
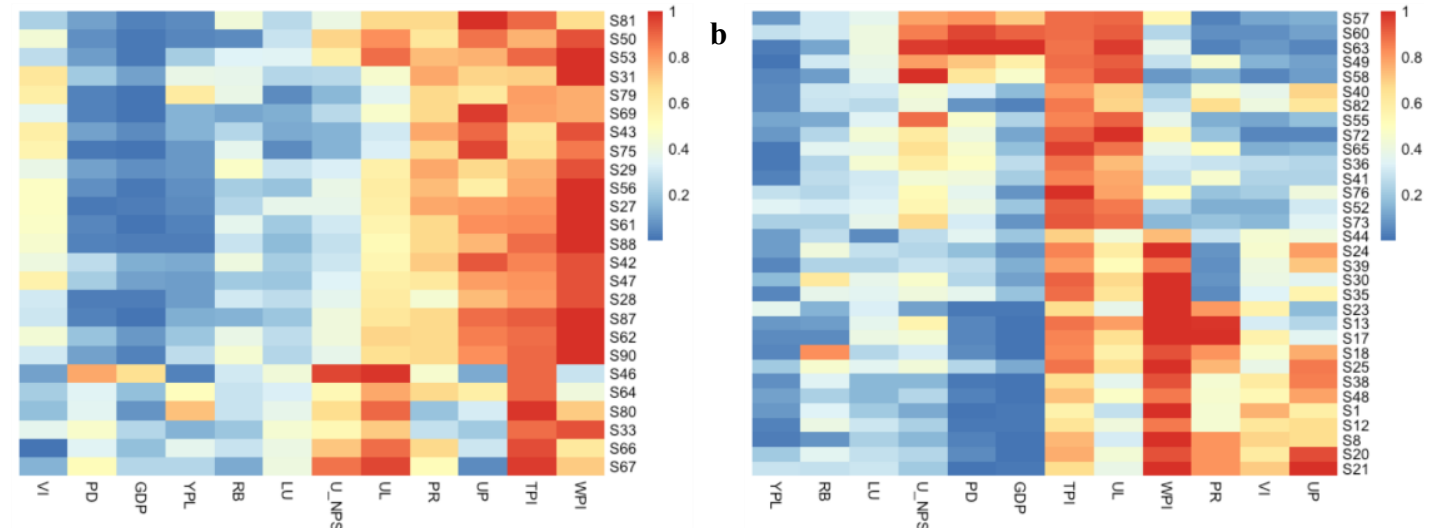

c
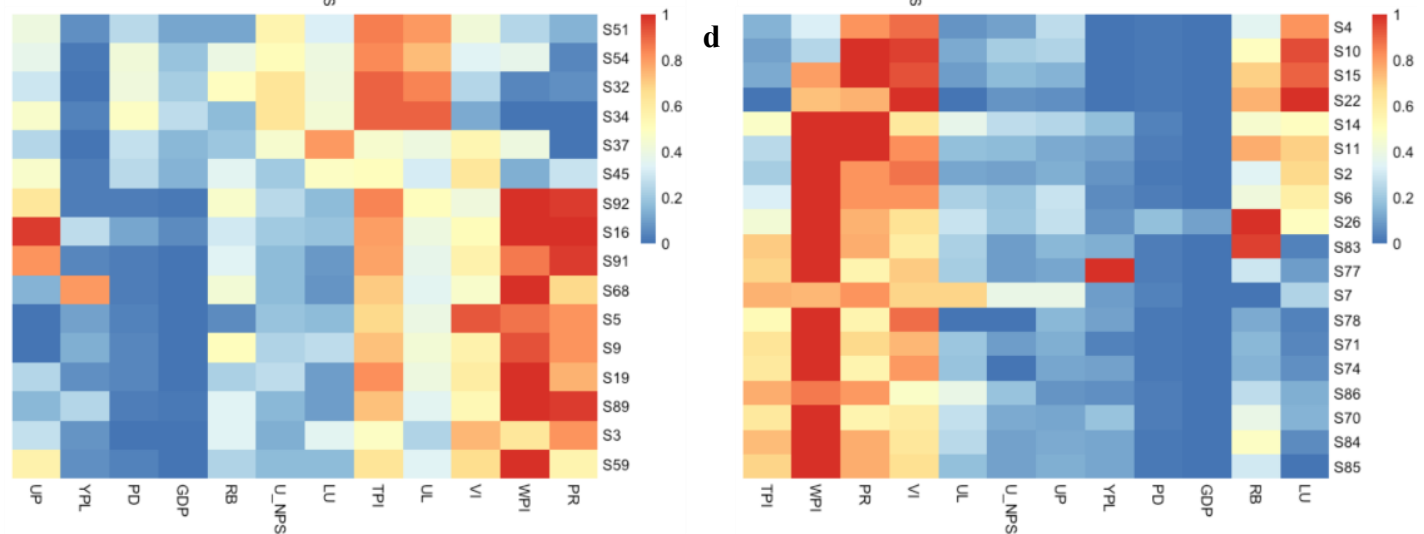

Fig. 8 Normalized index values of the assessment indices of the subwatersheds in

different priorities (a: subwatersheds of priority 5; b: subwatersheds of priority 4; c: 
subwatersheds of priority 3 ; d: subwatersheds of priority 2 and priority 1 )

\subsection{Limitation}

There may be some uncertainties due to the accuracy of the publicly-available data that we obtained. Therefore, high-resolution data and accurate drainage network datasets are still needed to improve the prioritization approach. However, simulating underground drainage networks remains challengeable in urban areas. In addition, it is also advised to add extra assessment index when expanding this approach to other regions based on regional characteristics (i.e., SC facility applicability and decision maker preferences). Consequently, the SC can be constructed to prevent and solve sitespecific and watershed-specific problems. Finally, to compute the overall priority index, the weights calculated by the AHP and CRITIC methods are equal, but some adjustments may be needed in the future studies.

\section{Conclusion}

The PI model was built based on multi-criteria in this study to prioritize SC planning at both the raster scale and regional scale to bridge the gap of opportunistic and empirical planning at the macro scale. The parameters were categorized into 4 criteria and 15 indexes through a literature review, brainstorming and expert interviews. Model coefficients were determined by the IAHP method.

The model was applied to the Beiyun watershed as a case study, and some findings were drawn. High-priority areas for SC construction were recognized in the emerging regions where large area of buildings and infrastructures have yet to be constructed, followed by developed areas with the highest urban level where the construction of SC 
should focus on flood control. Ecological protection areas and agricultural areas were considered as the lowest priority. Concurrently, these insights verified the rationality of the method. Additionally, clustering heatmaps showed that TPI, WPI, PR, UP, UL and VI were identified as key factors affecting the priority of SC planning. As such, the method and findings in this study will provide a reference for SC planning in other regions, even in the case of insufficient data.

Acknowledgements The authors extend their appreciation to the State Key Program of National Natural Science Foundation of China (No. 41530635), the Fund for the Innovative Research Group of the National Natural Science Foundation of China (No. 51721093), and the Interdisciplinary Research Funds of Beijing Normal University.

Authors' contributions Methodology, writing-Original draft preparation and software: Xiaoyue Zhang. Conceptualization, supervision and writing-Original draft preparation: Lei Chen. Investigation and software: Meng Zhang. Methodology, writing-Reviewing and editing: Zhenyao Shen.

Data availability The datasets used and/or analyzed during the current study are available from the corresponding author on reasonable request.

Funding This research was funded by the State Key Program of National Natural Science Foundation of China (No. 41530635), the Fund for the Innovative Research Group of the National Natural Science Foundation of China (No. 51721093), and the Interdisciplinary Research Funds of Beijing Normal University.

\section{Compliance with ethical standards}


522 Competing interests The authors have no financial or proprietary interests in any

523 material discussed in this article.

524 Ethical approval Not applicable

525 Consent to participate Not applicable

526 Consent to publish Not applicable

527 Supplementary Information

Details information about the SPARROW model, river water quality, source

529 apportionment, results of the pairwise comparison matrix of AHP method can be seen

530 in supplementary information. 


\section{References}

Ahiablame LM, Engel BA, Chaubey I (2012): Effectiveness of Low Impact Development Practices: Literature Review and Suggestions for Future Research. Water Air and Soil Pollution 223, 4253-4273

Apostolopoulou E, Bormpoudakis D, Paloniemi R, Cent J, Grodzińska-Jurczak M, Pietrzyk-Kaszyńska A, Pantis JD (2014): Governance rescaling and the neoliberalization of nature: the case of biodiversity conservation in four EU countries. International Journal of Sustainable Development \& World Ecology 21, $481-494$

Baek S-S, Ligaray M, Pyo J, Park J-P, Kang J-H, Pachepsky Y, Chun JA, Cho KH (2020): A novel water quality module of the SWMM model for assessing low impact development (LID) in urban watersheds. Journal of Hydrology 586, 124886

Ball G, Hall J (1965): A Novel Method of Data Analysis and Pattern Classification. Menlo Park, California: Stanford Research Institute

Beven KJ, Kirkby MJ (1979): A physically based, variable contributing area model of basin hydrology / Un modèle à base physique de zone d'appel variable de l'hydrologie du bassin versant. Hydrological Sciences Bulletin 24, 43-69

Brown HL, Bos DG, Walsh CJ, Fletcher TD, RossRakesh S (2016): More than money: how multiple factors influence householder participation in at-source stormwater management. Journal of Environmental Planning and Management 59, 79-97

Cao Z, Myers RJ, Lupton RC, Duan H, Sacchi R, Zhou N, Reed Miller T, Cullen JM, 

of the global cement cycle. Nature Communications 11, 3777

Chan FKS, Griffiths JA, Higgitt D, Xu S, Zhu F, Tang Y-T, Xu Y, Thorne CR (2018): "Sponge City" in China-A breakthrough of planning and flood risk management in the urban context. Land Use Policy 76, 772-778

Charlesworth S, Warwick F, Lashford C (2016): Decision-Making and Sustainable Drainage: Design and Scale. Sustainability 8, 782

Chatzimentor A, Apostolopoulou E, Mazaris AD (2020): A review of green infrastructure research in Europe: Challenges and opportunities. Landscape and Urban Planning 198, 103775

Diakoulaki D, Mavrotas G, Papayannakis L (1995): Determining objective weights in multiple criteria problems: The critic method. Computers \& Operations Research $22,763-770$

Dou Y, Kuang W (2020): A comparative analysis of urban impervious surface and green space and their dynamics among 318 different size cities in China in the past 25 years. Science of The Total Environment 706, 135828

Han Q, Tong R, Sun W, Zhao Y, Yu J, Wang G, Shrestha S, Jin Y (2020): Anthropogenic influences on the water quality of the Baiyangdian Lake in North China over the last decade. Science of The Total Environment 701, 134929

Hou J, Zhu M, Wang Y, Sun S (2020a): Optimal spatial priority scheme of urban LIDBMPs under different investment periods. Landscape and Urban Planning 202, 103858 
Hou X, Guo H, Wang F, Li M, Xue X, Liu X, Zeng S (2020b): Is the sponge city construction sufficiently adaptable for the future stormwater management under climate change? Journal of Hydrology 588, 125055

Ishaq S, Hewage K, Farooq S, Sadiq R (2019): State of provincial regulations and guidelines to promote low impact development (LID) alternatives across Canada: Content analysis and comparative assessment. Journal of Environmental Management 235, 389-402

Jia H, Yao H, Tang Y, Yu SL, Zhen JX, Lu Y (2013): Development of a multi-criteria index ranking system for urban runoff best management practices (BMPs) selection. Environmental Monitoring and Assessment 185, 7915-7933

Jia H, Wang Z, Zhen X, Clar M, Yu SL (2017): China's sponge city construction: A discussion on technical approaches. Frontiers of Environmental Science \& Engineering 11, 18

Lee JG, Selvakumar A, Alvi K, Riverson J, Zhen JX, Shoemaker L, Lai F-h (2012): A watershed-scale design optimization model for stormwater best management practices. Environmental Modelling \& Software 37, 6-18

Leng L, Mao X, Jia H, Xu T, Chen AS, Yin D, Fu G (2020): Performance assessment of coupled green-grey-blue systems for Sponge City construction. Science of The Total Environment 728, 138608

Li Q, Wang F, Yu Y, Huang Z, Li M, Guan Y (2019): Comprehensive performance evaluation of LID practices for the sponge city construction: A case study in Guangxi, China. Journal of Environmental Management 231, 10-20 
Lin K, Chen H, Xu C-Y, Yan P, Lan T, Liu Z, Dong C (2020): Assessment of flash flood risk based on improved analytic hierarchy process method and integrated maximum likelihood clustering algorithm. Journal of Hydrology 584, 124696

Lintern A, McPhillips L, Winfrey B, Duncan J, Grady C (2020): Best Management Practices for Diffuse Nutrient Pollution: Wicked Problems Across Urban and Agricultural Watersheds. Environmental Science \& Technology 54, 9159-9174

Liu Y, Bralts VF, Engel BA (2015): Evaluating the effectiveness of management practices on hydrology and water quality at watershed scale with a rainfall-runoff model. Science of The Total Environment 511, 298-308

Liu Y, Cibin R, Bralts VF, Chaubey I, Bowling LC, Engel BA (2016): Optimal selection and placement of BMPs and LID practices with a rainfall-runoff model. Environmental Modelling \& Software 80, 281-296

Luan B, Yin R, Xu P, Wang X, Yang X, Zhang L, Tang X (2019): Evaluating Green Stormwater Infrastructure strategies efficiencies in a rapidly urbanizing catchment using SWMM-based TOPSIS. Journal of Cleaner Production 223, 680-691

Luo Z, Shao Q, Zuo Q, Cui Y (2020): Impact of land use and urbanization on river water quality and ecology in a dam dominated basin. Journal of Hydrology 584, 124655

Martin-Mikle CJ, de Beurs KM, Julian JP, Mayer PM (2015): Identifying priority sites for low impact development (LID) in a mixed-use watershed. Landscape and Urban Planning 140, 29-41

Ministry of housing and urban-rural development (MOHURD) (2019). Assessment 
Mustafa A, Bruwier M, Archambeau P, Erpicum S, Pirotton M, Dewals B, Teller J (2018): Effects of spatial planning on future flood risks in urban environments. Journal of Environmental Management 225, 193-204

Nguyen TT, Ngo HH, Guo W, Wang XC (2020): A new model framework for sponge city implementation: Emerging challenges and future developments. Journal of Environmental Management 253, 109689

Osborn A (1957): Applied Imagination. New York: Scribner

Pantelidis P, Pazarskis M, Karakitsiou A, Dolka V (2018): Modeling an Analytic Hierarchy Process (AHP) assessment system for municipalities in Greece with public accounting of austerity. Journal of Accounting \& Taxation 10, 48-60

Pauleit S, Ennos R, Golding Y (2005): Modeling the environmental impacts of urban land use and land cover change — a study in Merseyside, UK. Landscape and Urban Planning 71, 295-310

Qin H-p, Li Z-x, Fu G (2013): The effects of low impact development on urban flooding under different rainfall characteristics. Journal of Environmental Management 129, $577-585$

Rauch W, Urich C, Bach PM, Rogers BC, de Haan FJ, Brown RR, Mair M, McCarthy DT, Kleidorfer M, Sitzenfrei R, Deletic A (2017): Modelling transitions in urban water systems. Water Research 126, 501-514

Richards JA (1986): Remote Sensing Digital Image Analysis: An Introduction. Berlin: Springer-Verlag 
Saaty T (1980): The Analytic Hierarchy Process: Planning, Priority Setting, Resource Allocation, Mc Graw-Hill, New York, pp. 19.

Shen Z, Hou X, Li W, Aini G, Chen L, Gong Y (2015): Impact of landscape pattern at multiple spatial scales on water quality: A case study in a typical urbanised watershed in China. Ecological Indicators 48, 417-427

Sulemana I, Nketiah-Amponsah E, Codjoe EA, Andoh JAN (2019): Urbanization and income inequality in Sub-Saharan Africa. Sustainable Cities and Society 48, 101544

Thu Thuy N, Huu Hao N, Guo W, Wang XC (2020): A new model framework for sponge city implementation: Emerging challenges and future developments. Journal of Environmental Management 253

Zhang J, Wei Z, Jia H, Huang X (2017): Factors influencing water quality indices in a typical urban river originated with reclaimed water. Frontiers of Environmental Science \& Engineering 11, 8

Zhang L, Sun X, Xue H (2019): Identifying critical risks in Sponge City PPP projects using DEMATEL method: A case study of China. Journal of Cleaner Production $226,949-958$

Zhang X, Zhi X, Chen L, Shen Z (2020): Spatiotemporal variability and key influencing factors of river fecal coliform within a typical complex watershed. Water Research 178,115835 


\section{Figures}

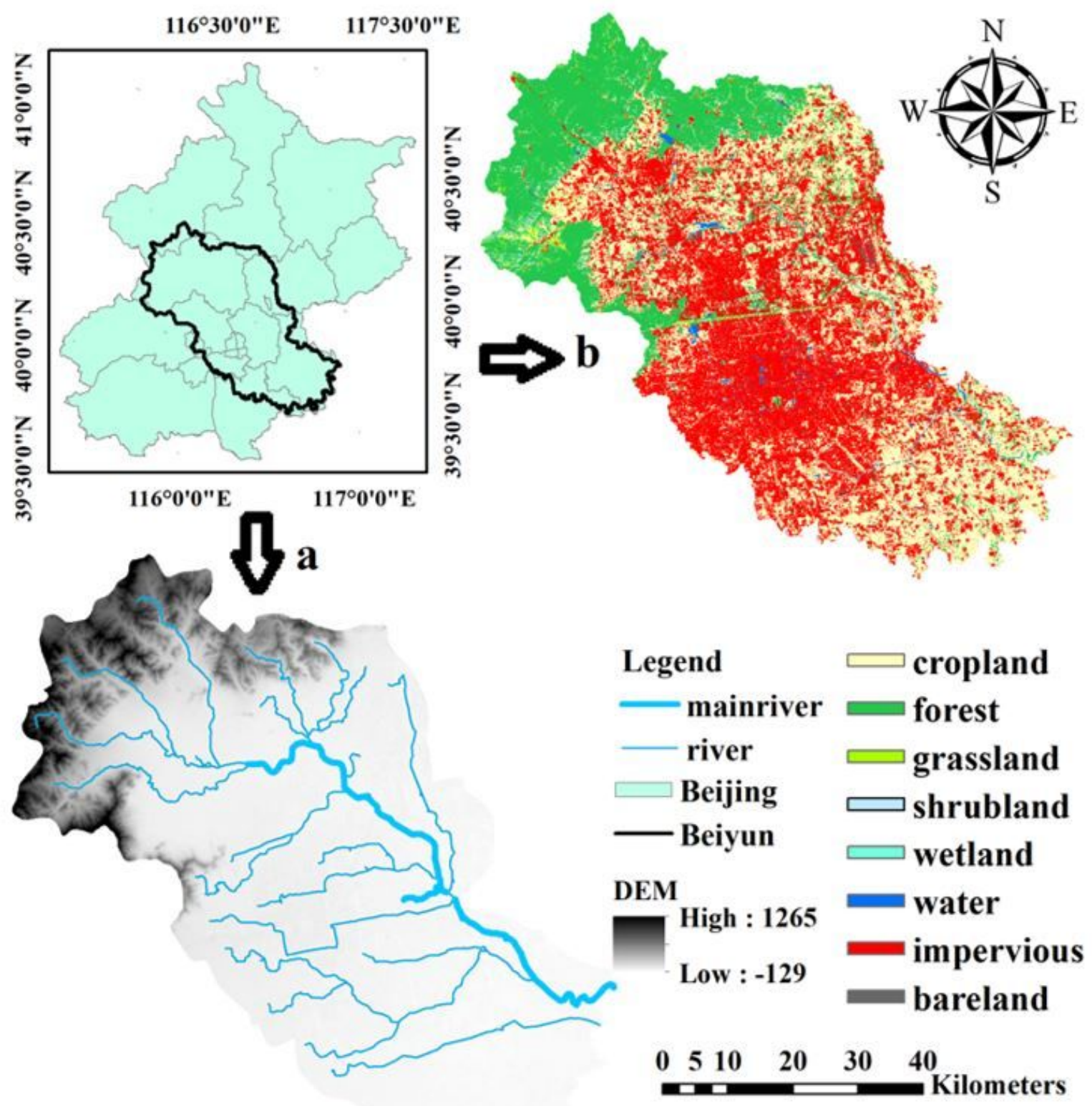

Figure 1

Land use and elevation in the Beiyun watershed Note: The designations employed and the presentation of the material on this map do not imply the expression of any opinion whatsoever on the part of Research Square concerning the legal status of any country, territory, city or area or of its authorities, or concerning the delimitation of its frontiers or boundaries. This map has been provided by the authors. 


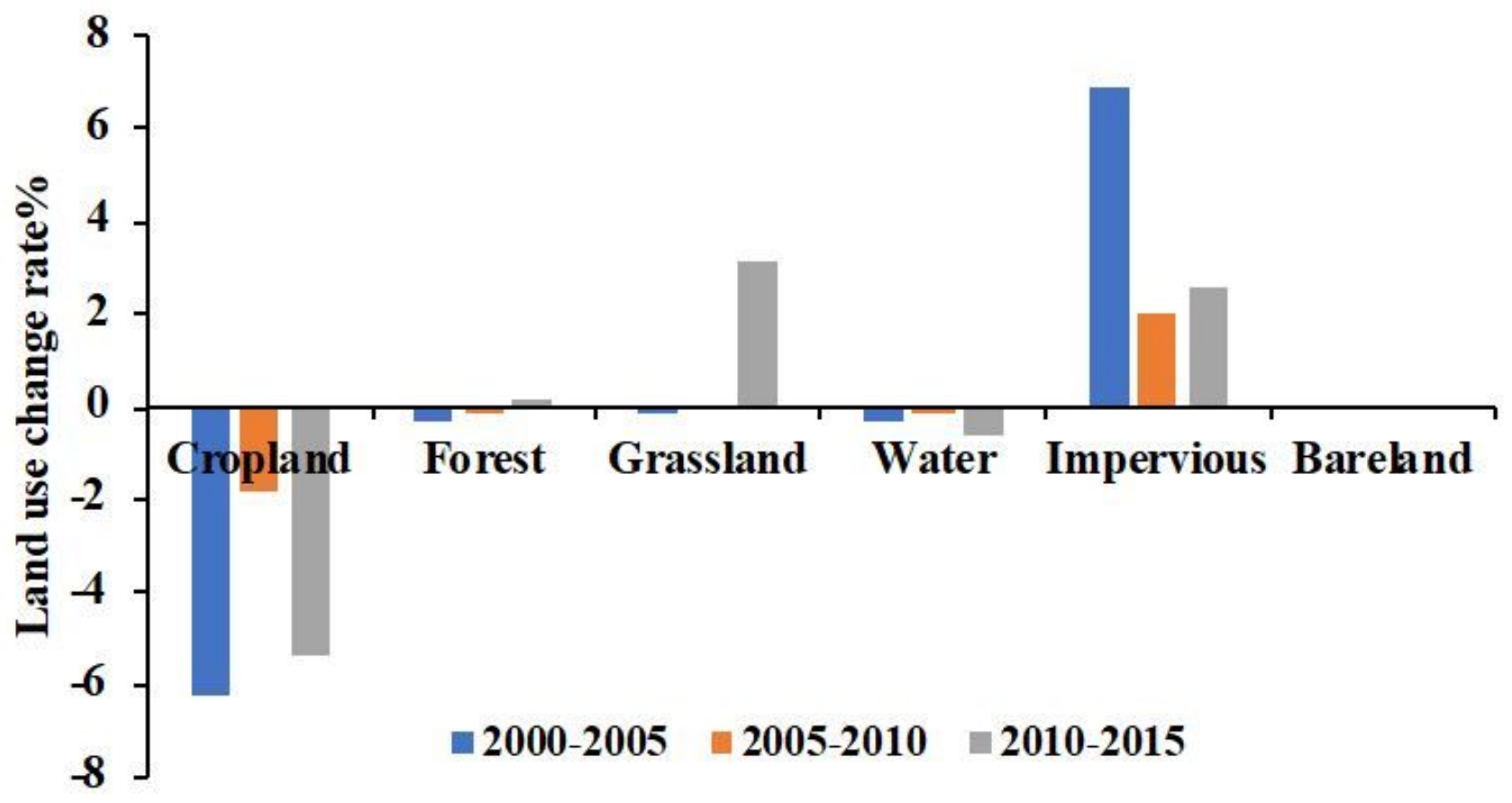

Figure 2

Land use change in the study area

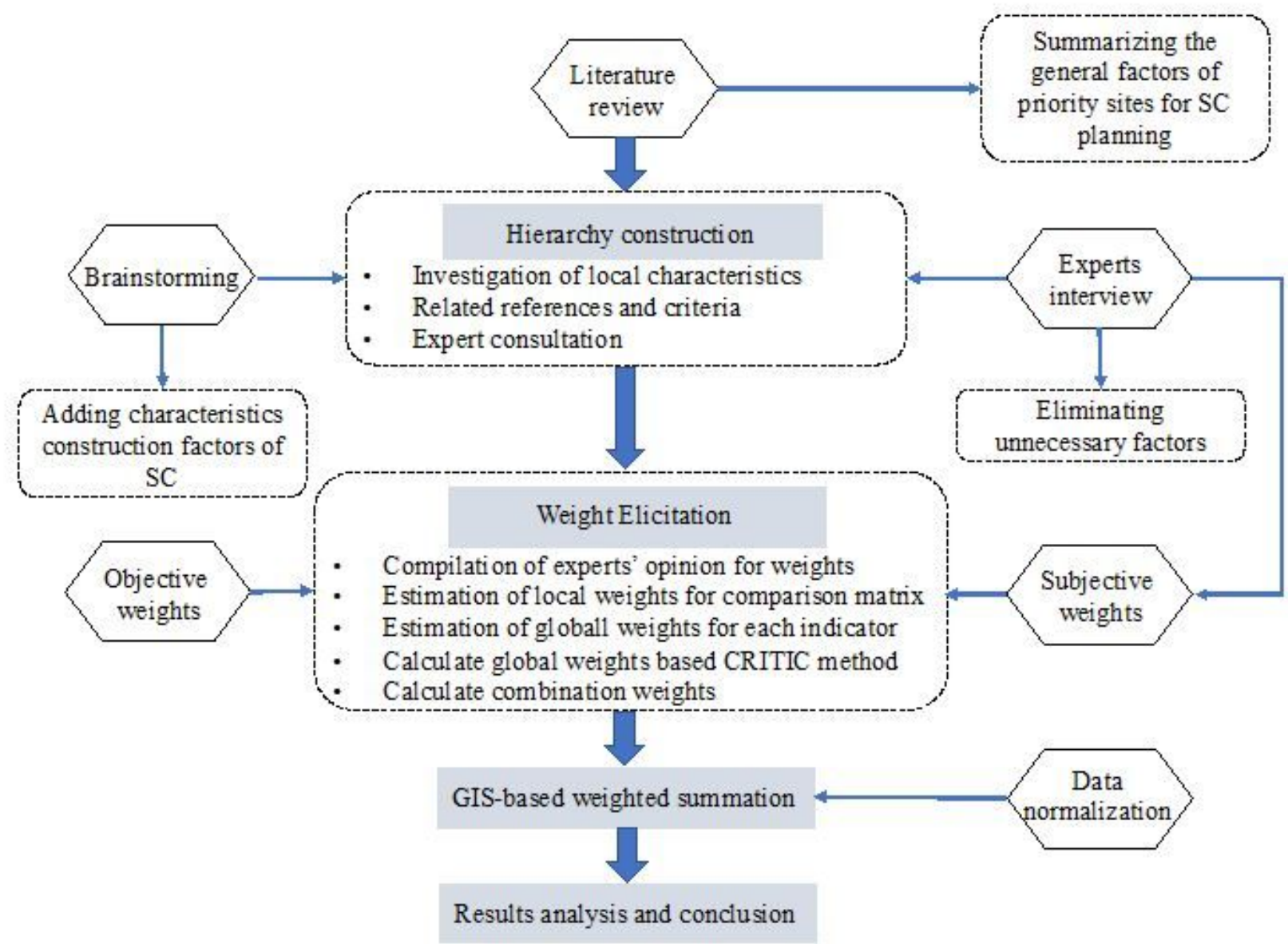


Figure 3

Framework of this study

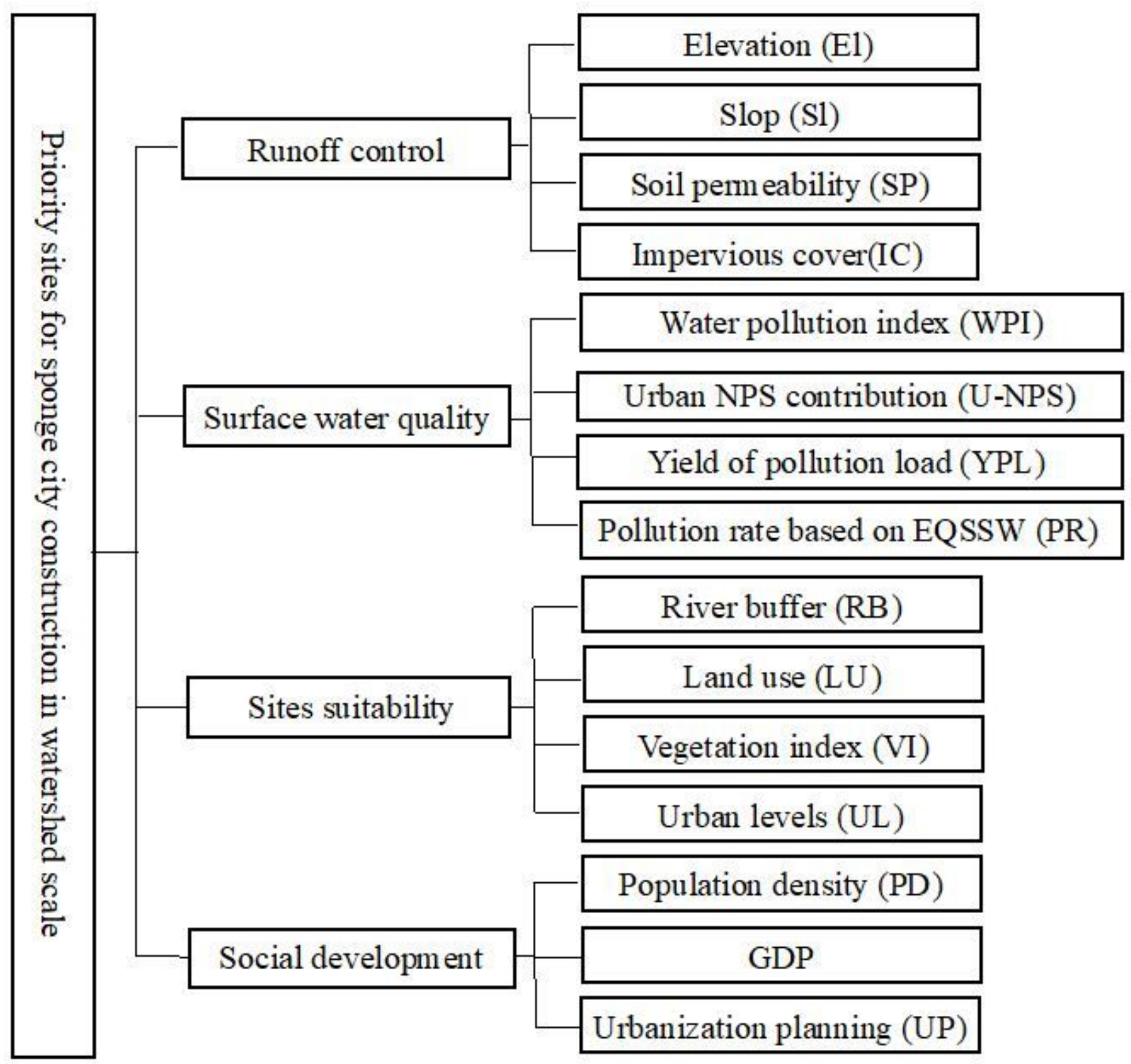

Figure 4

Hierarchical structure of SC planning in the Beiyun watershed 

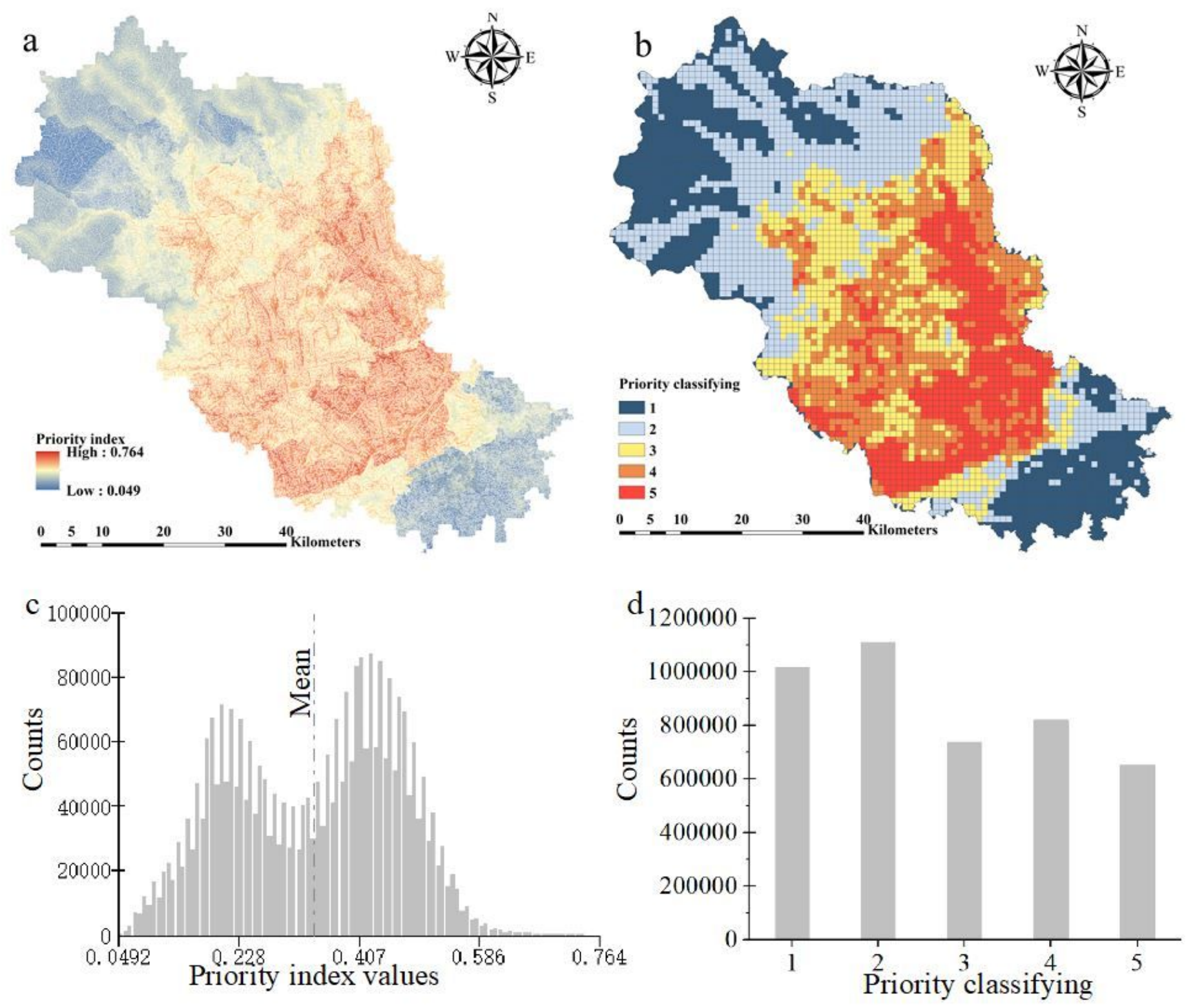

Figure 5

Spatial distribution of priority sites for SC construction in the Beiyun watershed Note: The designations employed and the presentation of the material on this map do not imply the expression of any opinion whatsoever on the part of Research Square concerning the legal status of any country, territory, city or area or of its authorities, or concerning the delimitation of its frontiers or boundaries. This map has been provided by the authors. 


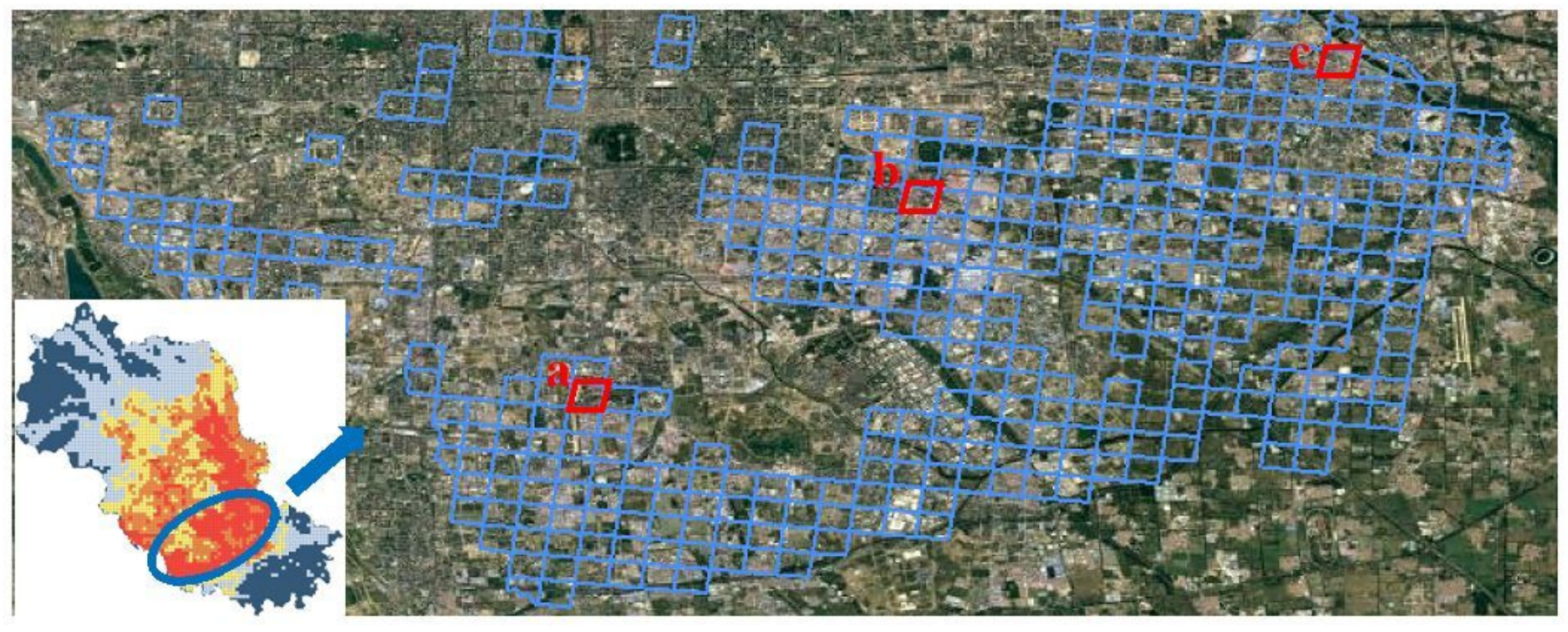

Figure 6

Sites validation of the priority for LID implementation Note: The designations employed and the presentation of the material on this map do not imply the expression of any opinion whatsoever on the part of Research Square concerning the legal status of any country, territory, city or area or of its authorities, or concerning the delimitation of its frontiers or boundaries. This map has been provided by the authors. 


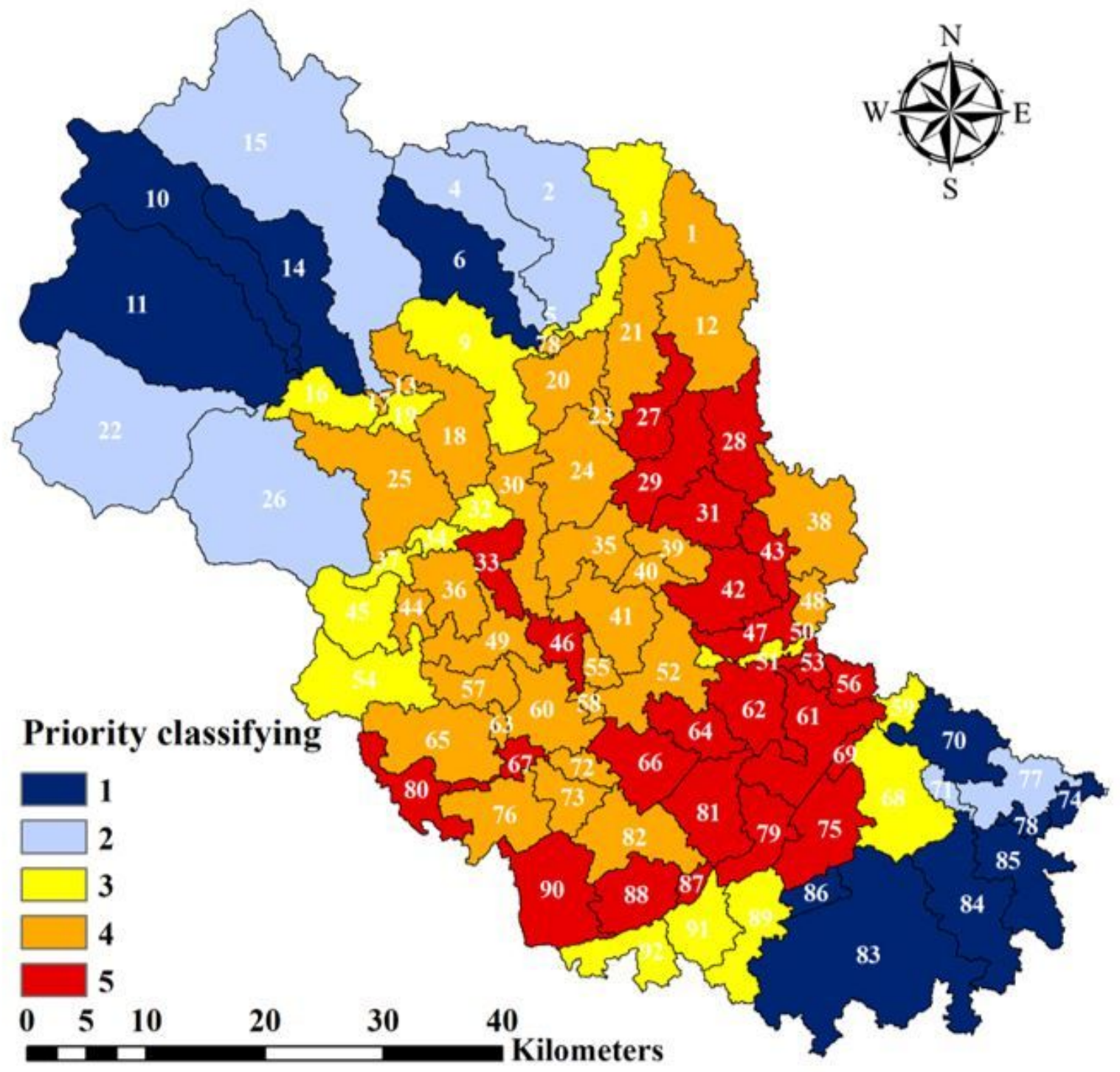

Figure 7

Priority of SC planning in subwatershed scale Note: The designations employed and the presentation of the material on this map do not imply the expression of any opinion whatsoever on the part of Research Square concerning the legal status of any country, territory, city or area or of its authorities, or concerning the delimitation of its frontiers or boundaries. This map has been provided by the authors. 
a

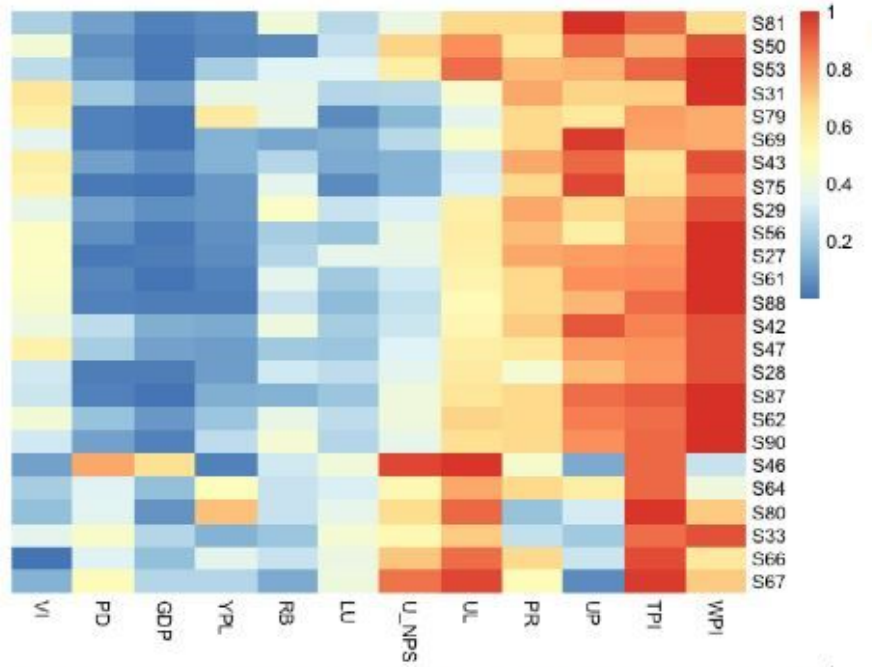

c

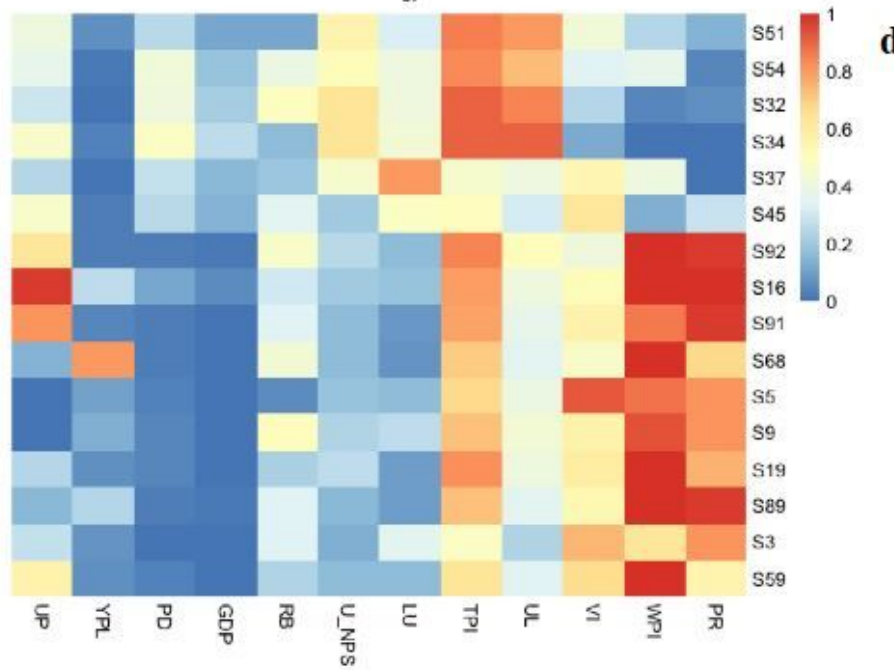

b
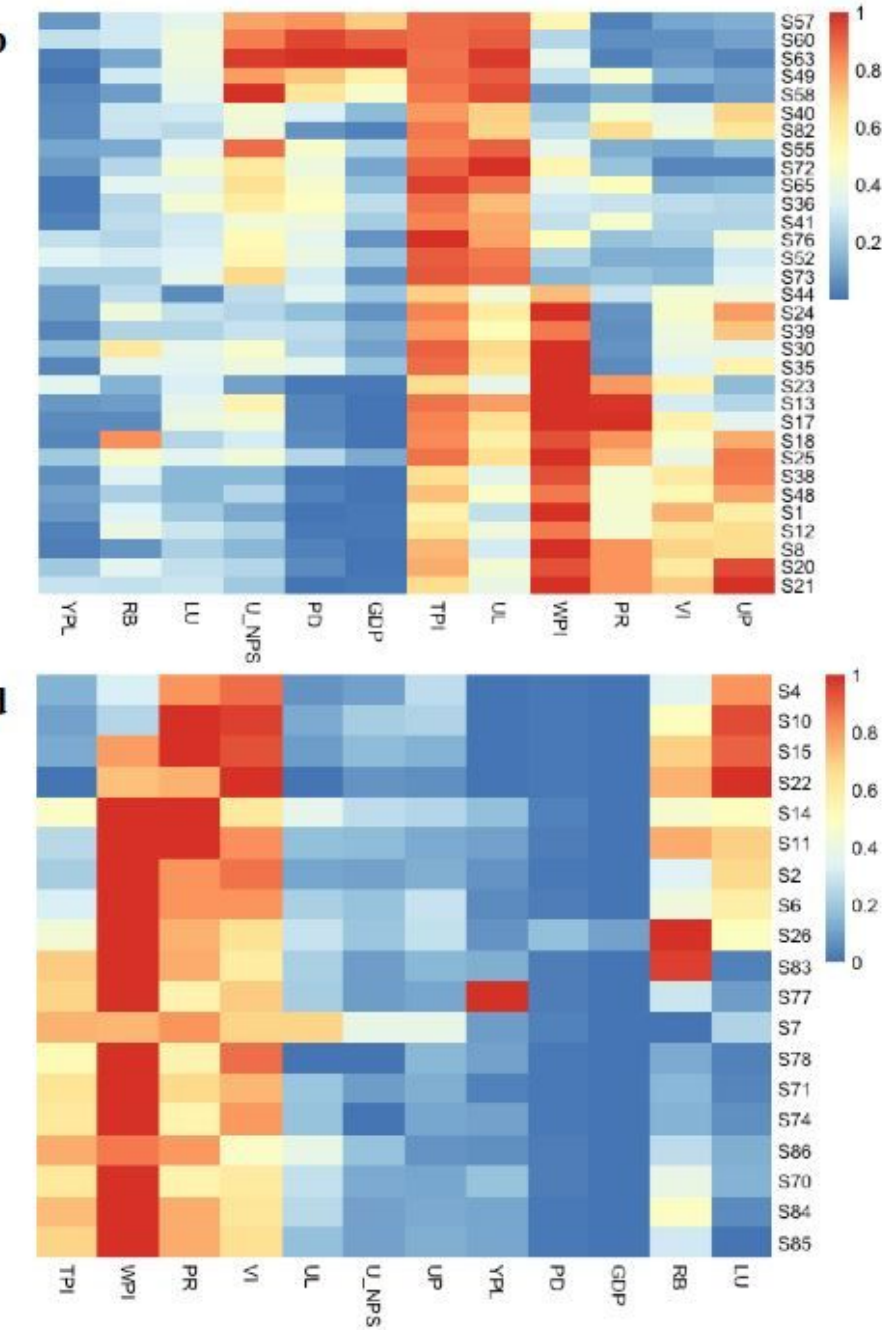

Figure 8

Normalized index values of the assessment indices of the subwatersheds in different priorities (a: subwatersheds of priority 5 ; b: subwatersheds of priority 4 ; c: subwatersheds of priority 3 ; d: subwatersheds of priority 2 and priority 1 )

\section{Supplementary Files}

This is a list of supplementary files associated with this preprint. Click to download.

- Supplementarymaterial.docx 